Article

\title{
Characterization of a Metagenome-Derived $\beta$-Glucosidase and Its Application in Conversion of Polydatin to Resveratrol
}

\author{
Zhimao Mai, Hongfei Su and Si Zhang *
}

CAS Key Laboratory of Tropical Marine Bio-Resources and Ecology, South China Sea Institute of Oceanology, Chinese Academy of Sciences, Guangzhou 510301, China; maizhimao@163.com (Z.M.); shf2016@sina.com (H.S.)

* Correspondence: zhsimd@scsio.ac.cn; Tel.: +86-20-8902-3105; Fax: +86-20-8445-1672

Academic Editor: David D. Boehr

Received: 8 December 2015; Accepted: 19 February 2016; Published: 1 March 2016

\begin{abstract}
For the beneficial pharmacological properties of resveratrol, there is increasingly interest in enzymatic conversion of polydatin to resveratrol. The metagenomic technique provides an effective strategy for mining novel polydatin-hydrolysis enzymes from uncultured microorganisms. In this study, a metagenomic library of mangrove soil was constructed and a novel $\beta$-glucosidase gene MlBgl was isolated. The deduced amino acid sequences of MlBgl showed the highest identity of $64 \%$ with predicted $\beta$-glucosidase in the GenBank database. The gene was cloned and overexpressed in Escherichia coli BL21(DE3). Sodium dodecyl sulfate-polyacrylamide gel electrophoresis (SDS-PAGE) assay demonstrated the purified recombinant $\beta$-glucosidase r-MlBgl with a molecular weight approximately of $71 \mathrm{kDa}$. The optimal $\mathrm{pH}$ and temperature of purified recombinant $\mathrm{r}-\mathrm{MlBgl}$ were 7.0 and $40{ }^{\circ} \mathrm{C}$, respectively. $\mathrm{r}-\mathrm{MlBgl}$ could hydrolyze polydatin effectively. The $k_{\text {cat }}$ and $k_{\text {cat }} / K_{\mathrm{m}}$ values for polydatin were $989 \mathrm{~s}^{-1}$ and $1476 \mathrm{mM}^{-1} \cdot \mathrm{s}^{-1}$, respectively. These properties suggest that $-\mathrm{r}-\mathrm{MlBgl}$ has potential application in the enzymatic conversion of polydatin to resveratrol for further study.
\end{abstract}

Keywords: $\beta$-glucosidase; mangrove soil; metagenomic library; polydatin; resveratrol

\section{Introduction}

Resveratrol (3,4',5-trihydroxystilbene), a non-flavonoid polyphenolic compound, reportedly has a wide range of pharmacological properties, including antitumor, antithrombosis, antiatherosclerosis, antioxidant, and antiinflammatory [1-3]. It was listed as one of the most promising drugs for anti-cancer and anti-cardiovascular disease [4]. Resveratrol has been developed as a dietary supplement and food additive due to its multiple biological and pharmacological activities. There is increasing demand for resveratrol in food and health products. Currently, resveratrol is mainly obtained from natural plants by solvent extraction. However, there is only a small concentration of resveratrol (about $0.2 \%$ ) in plants and it is expensive to obtain large quantities by large-scale extraction. It was reported that polydatin (resveratrol-3-O- $\beta$-D-glucoside), the glycoside form of the precursor of resveratrol, is 10-15 times higher than resveratrol [5,6]. Therefore, to obtain resveratrol more effectively and economically, the conversion of polydatin to resveratrol by cleaving the glucoside has been proved to be a feasible procedure.

$\beta$-Glucosidases ( $\beta$-D-glucopyranoside glucohydrolases, E.C. 3.2.1.21) catalyze the hydrolysis of $\beta$-glucosidic linkages of various oligosaccharides and glycosides to form glucose and a shorter/debranched oligosaccharide [7]. $\beta$-Glucosidases have many applications in biological processes, such as hydrolysis of cellulose to produce ethanol [8], synthesis of alkyl glucoside and gentiooligaccharide [9], improving the flavor in food processing [10], hydrolysis of isoflavone glycosides [11], and conversion of polydatin to resveratrol [12]. Among the above mentioned 
biotechnological processes, hydrolysis of polydatin is an application with high commercial value. Compared with acid and heating hydrolysis, microbial and enzymatic conversion of polydatin to resveratrol only requires mild conditions, simple procedures, and results in less pollution [13]. Many studies on the microbial conversion of polydatin to resveratrol with various microorganisms have been reported $[5,6,14,15]$. Although the yield of resveratrol was increased, the long fermentation time and low productivity greatly restricted its industrial application. Enzymatic conversion of polydatin has been suggested to be the most efficient technique. Recently, researchers investigated the conversion of polydatin to resveratrol by using $\beta$-glucosidase from Aspergillus oryzae and Lactobacillus kimchi $[12,16,17]$. However, the catalytic efficiency of these $\beta$-glucosidases was still not satisfied due to their low hydrolysis activity. Moreover, these $\beta$-glucosidases that hydrolyse polydatin were from cultured microorganisms and little attention had been paid to $\beta$-glucosidases from unculturable microorganisms. More than $99 \%$ of the microorganisms cannot be cultured using conventional methods, which leaves a great deal of industry-potential $\beta$-glucosidases unmined [18]. The metagenomic approach has been successfully employed in the isolation and identification of novel $\beta$-glucosidases from various samples [19-22]. Nevertheless, the hydrolysis activity of these $\beta$-glucosidases for polydatin has not been investigated until now. Therefore, screening novel $\beta$-glucosidases with high conversion efficiency for polydatin from the metagenomic library is urgently demanded.

In this study, a novel gene MlBgl was isolated from the mangrove soil metagenomic library by functional screening. The recombinant $\beta$-glucosidase $\mathrm{r}-\mathrm{MlBgl}$ was purified and characterized. The conversion of polydatin to resveratrol with metagenome-derived $\beta$-glucosidase was investigated for the first time.

\section{Results and Discussion}

\subsection{Construction of the Metagenomic Library and Screening for Clones with $\beta$-Glucosidase Activity}

A fosmid library of 100,000 clones was constructed using the metagenomic DNA isolated from mangrove soil. Restriction analysis of randomly selected recombinant plasmids revealed a high level of diversity of the foreign DNA fragments. The insert sizes ranged from 20 to $55 \mathrm{~kb}$, with an average size of $30 \mathrm{~kb}$ [23]. The fosmid library possessed a capacity of approximately $3 \mathrm{~Gb}$ insertion DNA. Seventeen clones with $\beta$-glucosidase activity were isolated from 10,000 clones by function-based strategy. The positive fosmid clones were surrounded by a black spot on the selective plates after incubation at $37^{\circ} \mathrm{C}$ for $24 \mathrm{~h}$, indicating the activity of $\beta$-glucosidase. The positive rate of the $\beta$-glucosidase activity clone in the fosmid library was approximately $17 / 10,000$ which is higher than some metagenomic libraries $[24,25]$. After screening the $\beta$-glucosidase activity from the fosmid library, the positive fosmid clones were rescreened for hydrolytic activity toward polydatin. Finally, one independent clone fosSCSIO2 with the highest activity toward polydatin was selected for further study.

\subsection{Sequence Analysis}

The plasmid from fosmid clone fosSCSIO2 was extracted and subcloned. The positive subclone of plasmid pUC-MlBgl was sequenced. Sequence analysis showed that pUC-MlBgl contained an open reading frame (ORF) coding for $\beta$-glucosidase. The overall $G+C$ content of the ORF was $59 \%$. The deduced protein product consisted of 663 amino acids which contained a catalytic domain belonging to glycosyl hydrolase family 3 according to the CAZy database (http:// prosite.expasy.org/). A signal peptide (residues 1-33) was found by the analysis of SignalP (version 4.1, http://www.cbs.dtu.dk/services/SignalP/). The predicted molecular mass of the protein was estimated to be $71.2 \mathrm{kDa}$. The deduced protein showed highest identity with a predicted $\beta$-glucosidase from Sphingomonas sp. LH128 (64\% identity) in the GenBank database. The secondary structures of $\mathrm{r}-\mathrm{MlBgl}$ and structure-based sequences alignment with $\beta$-D-glucan exohydrolase isoenzyme ExoI are shown in Figure 1. Multiple sequence alignment revealed that 
r-MlBgl shared the glycosyl hydrolase family 3 catalytic central conserved region Ser-Asp-Trp [26,27]. The conserved and similar amino acids are indicated by boxes and the predicted catalytic nucleophile residue Asp333 and acid/base residue Glu530 are indicated by filled triangles.

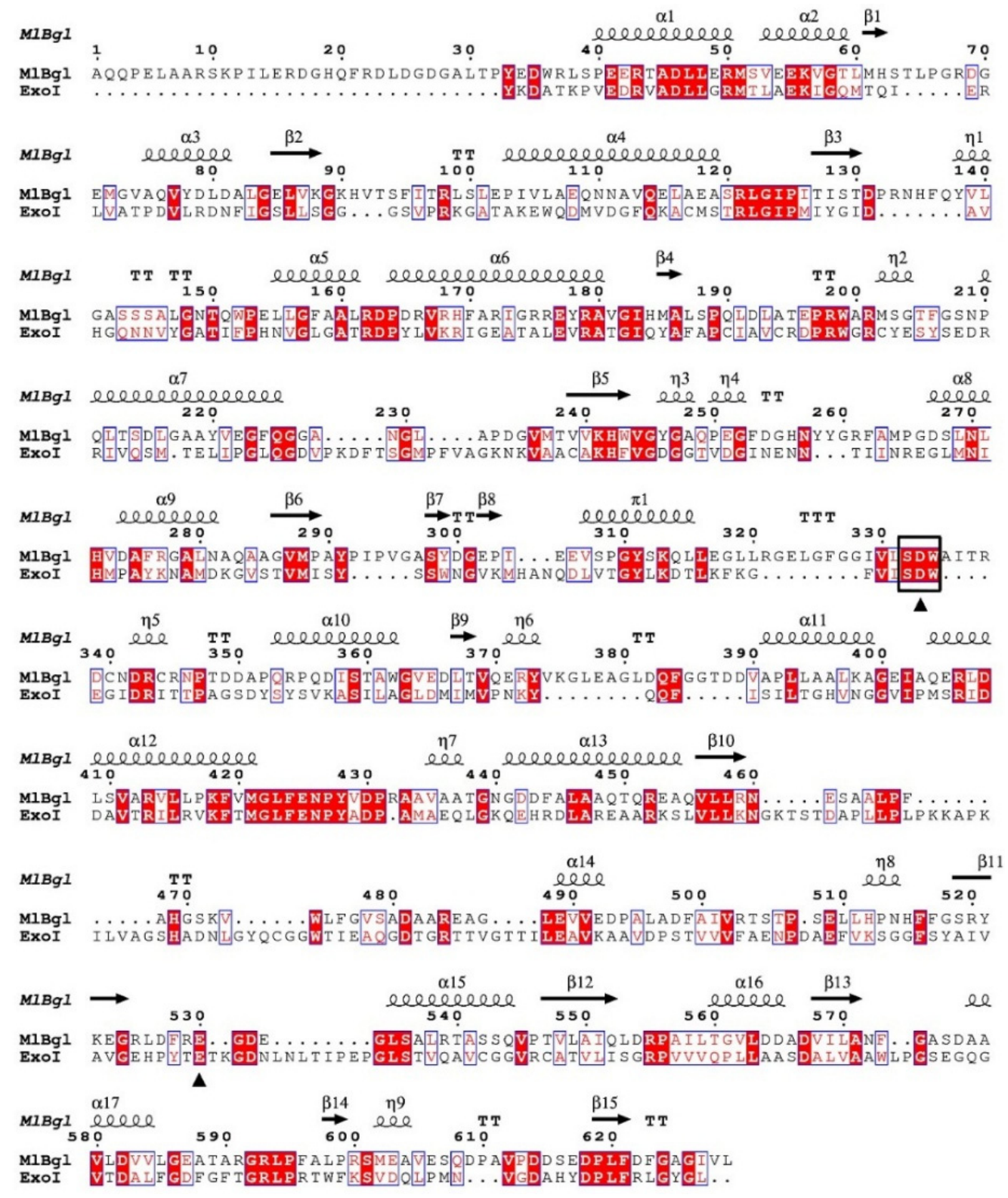

Figure 1. The secondary structures of r-MlBgl and structure-based sequences alignment with $\beta$-D-glucan exohydrolase isoenzyme Exol. The secondary structures and their designations are shown: arrows and coils represent the $\beta$-strands and $\alpha$-helices respectively. The glycosyl hydrolase family 3 catalytic central conserved region Ser-Asp-Trp is boxed. The catalytic nucleophile residue Asp333 and acid/base residue Glu530 are indicated by filled triangles. The structure-based sequences alignment was carried out by the Swiss-Model server and the secondary structure was assigned with ESPript 3.0 (http:/ / espript.ibcp.fr/ESPript/cgi-bin/ESPript.cgi).

The 3D model structure of $\mathrm{r}-\mathrm{MlBgl}$ was predicted based on the crystal structure of $\beta$-D-glucan exohydrolase isoenzyme ExoI by using the Swiss-Model server (Figure 2). The quality of the predicted model r-MlBgl was acceptable by checking using the Ramachandran plot. The structure of r-MlBgl contains two domain architecture, corresponding to the Glyco_hydro_3 (residues 117-449) and Glyco_hydro_3_C (residues 490-661) domain families. Domain 1 forms an $(\alpha / \beta)_{8}$ barrel and the 
second domain forms an $(\alpha / \beta)_{6}$ sheet. The active site cleft is formed by the interface of domains 1 and 2 in both monomers. $\beta$-Glucosidase has a retaining catalytic mechanism [28], the residue Asp functions as the catalytic nucleophile by attacking at the substrate anomeric center to form a covalent $\alpha$-D-glucosyl enzyme intermediate, while the other residue Glu/His acts as an acid/base catalyst by protonating the glycosidic oxygen in the first step and deprotonating the nucleophilic water molecule in the second step [29]. Asp333 in domain 1 and Glu530 in domain 2 were well aligned with the catalytic residues (Asp285 and Glu491) in HvExoI [30], suggesting that Asp333 and Glu530 may act as the catalytic nucleophile and acid/base, respectively. According to the 3D model structure of HvExoI, the residues Val87, Leu187, Thr368, and Trp474 were considered important and may participate in substrate recognition and binding. However, due to limitations of current homology 3D model structures and modeling methods, the crucial residues of $\mathrm{r}-\mathrm{MlBgl}$ for the catalysis are required for a detailed structural comparative analysis and further site directed mutation assay.

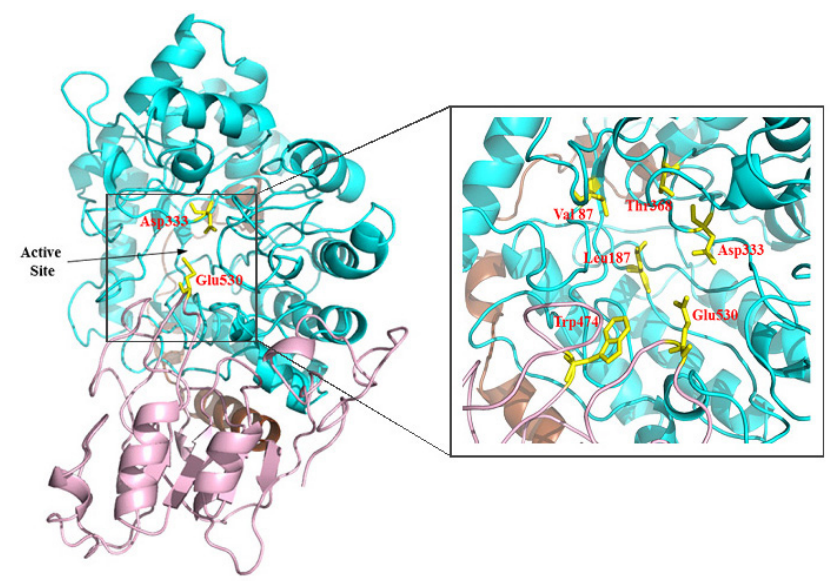

Figure 2. The three-dimensional model of r-MlBgl predicted by homology modelling based on the crystal structure of barley ExoI. The domain 1, the domain 2, and the linker are colored in cyan, lightpink, and wheat, respectively. The predicted nucleophile and acid/base catalyst active site residues of r-MlBgl (Asp333 and Glu530 respectively) are represented as sticks and shown in yellow. The catalytic residues and other conserved residues forming the substrate binding site are shown as sticks in the boxed panel. The picture was generated in PyMOL software(version 1.8, www.pymol.org).

\subsection{Enzyme Overexpression and Purification}

The $\beta$-glucosidase gene MlBgl was overexpressed in Escherichia coli BL21(DE3) cells. The recombinant $\mathrm{r}$-MlBgl with an $\mathrm{N}$-terminal $6 \times$ His-tagged protein was purified with $\mathrm{Ni}^{2+}$-NTA chromatography. SDS-PAGE analysis showed that r-MlBgl was purified to homogeneity, with a molecular mass approximately of $71 \mathrm{kDa}$ which corresponded to the calculated mass (Figure 3).

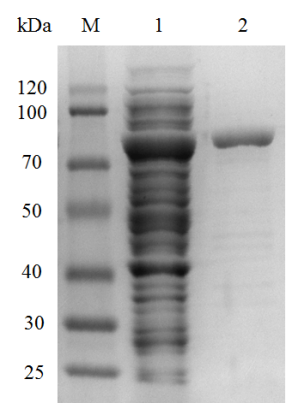

Figure 3. A $10 \%$ SDS-PAGE analysis of the purified r-MlBgl. M protein marker; 1 recombinant Escherichia coli BL21(DE3) harboring pET-MlBgl induced with IPTG; 2 purified r-MlBgl. 


\subsection{Physico-Chemical Characterization of $r-M l B g l$}

Figure 4a shows that $\mathrm{r}-\mathrm{MlBgl}$ was most active at $\mathrm{pH}$ 7.0. The optimal temperature of r-MlBgl was determined to be $40^{\circ} \mathrm{C}$ (Figure $4 \mathrm{~b}$ ). The optimal $\mathrm{pH}$ and temperature of r-MlBgl was similar to $\beta$-glucosidase isolated from the metagenomic library of mangrove soil [20]. r-MlBgl maintained more than $50 \%$ activity at temperatures from 25 to $35{ }^{\circ} \mathrm{C}$ and approximately $10 \%$ activity at $0{ }^{\circ} \mathrm{C}$, indicating it was a cold adapted enzyme. The cold adapted $\beta$-glucosidases have the advantage in reaction of requiring low temperature, such as increasing resveratrol in wine [31]. Also, they can offer economic benefits through energy savings in food processing or bioconversion [32]. The activity of r-MlBgl was stable at a temperature below $30^{\circ} \mathrm{C}$, but its activity decreased dramatically when the temperature climbed up to $35^{\circ} \mathrm{C}$ after incubating for $1 \mathrm{~h}$ (Figure $4 \mathrm{~b}$ ). The cold-active enzymes were usually highly active at low temperature but thermolabile [33]. Compared with some cold-active $\beta$-glucosidases, r-MlBgl showed higher thermostability at $30{ }^{\circ} \mathrm{C}[32,34,35]$. High hydrolytic efficiency and thermostability are both important properties in industrial application. Althought r-MlBgl exhibited higher activity at low temperature than thermophilic $\beta$-glucosidases [36,37], the lower thermostability limited its application. It was reported that the activity and thermostability of cold-active enzymes could be co-evolutionary [38], so direct evolution work of improving the activity and thermostability of r-MlBgl is now under study.

a

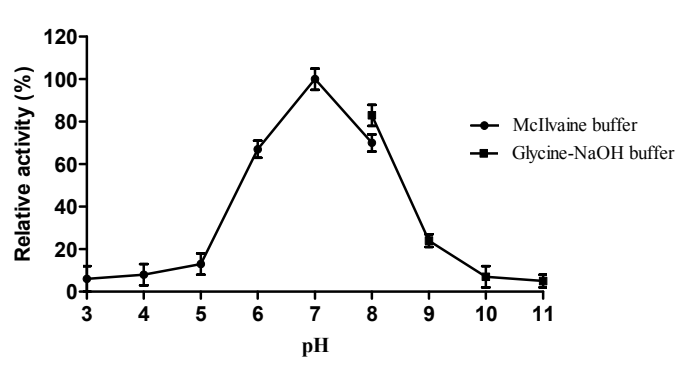

b

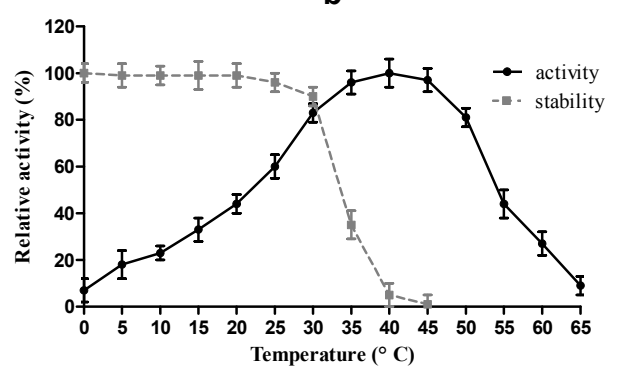

Figure 4. Effects of $\mathrm{pH}$ and temperature on the activity of the purified r-MlBgl. (a) Effect of $\mathrm{pH}$ on $\mathrm{r}-\mathrm{MlBgl}$ activity. The effect of $\mathrm{pH}$ on $\mathrm{r}-\mathrm{MlBgl}$ activity was determined between $\mathrm{pH} 3.0-11.0$ at $40{ }^{\circ} \mathrm{C}$; (b) Effect of temperature on r-MlBgl activity and thermostability assay. The activity was determined in McIlvaine buffer ( $\mathrm{pH} 7.0)$ at various temperatures $\left(0\right.$ to $\left.65^{\circ} \mathrm{C}\right)$; Thermostability of r-MlBgl was assayed after pre-incubation at temperatures 0 to $45^{\circ} \mathrm{C}$ for $1 \mathrm{~h}$. The error bars represent the means $\pm \operatorname{SD}(n=3)$.

Activity of r-MlBgl in the presence of $1 \mathrm{mM}$ and $10 \mathrm{mM}$ concentration of different metal ions or chemical reagents is shown in Table 1. Most metal ions had no significant inhibition on the activity of r-MlBgl except $\mathrm{Zn}^{2+}, \mathrm{Ba}^{2+}$, and $\mathrm{Cu}^{2+}$ at $1 \mathrm{mM}$ concentration. Whereas, $\mathrm{Ca}^{2+}, \mathrm{Ni}^{2+}, \mathrm{Co}^{2+}, \mathrm{EDTA}$, and SDS at $10 \mathrm{mM}$ were also potential inhibitors.

\subsection{Substrate Specificity and Enzymatic Kinetics}

To investigate the substrate specificity, activities of r-MlBgl towards different substrates were assayed (Table 2). $\mathrm{r}$-MlBgl proved to be most active toward polydatin, and showed high activity on $p$-nitrophenyl- $\beta$-D-glucopyranoside ( $p$ NPG) and esculin, indicating that r-MlBgl could hydrolyze aryl $\beta$-glycosidic bonds effectively. r-MlBgl exhibited weak activities toward $p$-nitrophenyl- $\beta$-D-galactopyranoside and $p$-nitrophenyl- $\beta$-D-xylopyranoside but no detectable activity toward $p$-nitrophenyl- $\beta$-D-cellobioside. It was similar to the $\beta$-glucosidases BglA and BglJ from Aspergillus oryzae which could hydrolyze $p$-nitrophenyl- $\beta$-D-xylopyranoside slowly but with no detectable activity toward $p$-nitrophenyl- $\beta$-D-cellobioside [39]. For the oligosaccharides and polysaccharides, r-MlBgl showed no activities toward cellobioside, cellotriose, carboxymethyl cellulose, avicel, and starch, indicating that $\mathrm{r}-\mathrm{MlBgl}$ could not hydrolyze the oligosaccharides and polysaccharides form by $\beta-(1,4), \alpha-(1,4)$, and $\alpha-(1,6)$ glycosidic bonds. The substrate specificity analysis 
suggested that $\mathrm{r}-\mathrm{MlBgl}$ possessed strong substrate specificity. It could only hydrolyze aryl $\beta$-glycosides and had no hydrolysis activities toward oligosaccharides and polysaccharides. According to the classification by substrate specificity, r-MlBgl belongs to aryl $\beta$-glucosidase [40].

Table 1. Effect of 1 or $10 \mathrm{mM}$ metal ions and chemical reagents on the activity of r-MlBgl.

\begin{tabular}{|c|c|c|}
\hline \multirow{2}{*}{ Reagents } & \multicolumn{2}{|c|}{ Relative Activity (\%) ${ }^{a}$} \\
\hline & Concentration $(1 \mathrm{mM})$ & Concentration $(10 \mathrm{mM})$ \\
\hline None & $100.0 \pm 2.6^{b}$ & $100.0 \pm 4.2$ \\
\hline $\mathrm{Na}^{+}$ & $98.9 \pm 5.4$ & $81.53 \pm 3.4$ \\
\hline $\mathrm{K}^{+}$ & $104.5 \pm 2.5$ & $85.6 \pm 3.2$ \\
\hline $\mathrm{Li}^{+}$ & $91 \pm 3.6$ & $80 \pm 4.1$ \\
\hline $\mathrm{NH}_{4}^{+}$ & $102.4 \pm 4.2$ & $93.3 \pm 4.8$ \\
\hline $\mathrm{Mg}^{2+}$ & $104.1 \pm 4.3$ & $88.1 \pm 3.5$ \\
\hline $\mathrm{Fe}^{3+}$ & $96.5 \pm 3.2$ & $58.8 \pm 3.6$ \\
\hline $\mathrm{Zn}^{2+}$ & $12.3 \pm 2.4$ & $5.7 \pm 1.1$ \\
\hline $\mathrm{Ca}^{2+}$ & $58.4 \pm 4.3$ & $45.6 \pm 2.9$ \\
\hline $\mathrm{Cu}^{2+}$ & $8.2 \pm 2.3$ & $5.9 \pm 1.4$ \\
\hline $\mathrm{Ni}^{2+}$ & $82.4 \pm 4.2$ & $59.3 \pm 3.8$ \\
\hline $\mathrm{Ba}^{2+}$ & $44.5 \pm 3.4$ & $23.4 \pm 3.1$ \\
\hline $\mathrm{Co}^{2+}$ & $66.1 \pm 3.5$ & $44.7 \pm 4.6$ \\
\hline EDTA & $56.4 \pm 4.7$ & $25.9 \pm 3.8$ \\
\hline SDS & $76.4 \pm 4.8$ & $55.2 \pm 3.1$ \\
\hline
\end{tabular}

${ }^{a}$ Assay was performed under optimum conditions; ${ }^{b}$ Values represent the means $\pm \operatorname{SD}(n=3)$.

Table 2. Substrate specificity of $r$-BglNH.

\begin{tabular}{ccc}
\hline Substrates & Configuration of Glycoside Linkage & Specific Activity $\left(\mathbf{U} \cdot \mathbf{m g}^{-1}\right)^{\mathbf{a}}$ \\
\hline Aryl $\beta$-glycosides & - & - \\
$p$-Nitrophenyl- $\beta$-D-glucopyranoside & $\beta$-Glucose & 248.26 \\
$p$-Nitrophenyl- $\beta$-D-galactopyranoside & $\beta$-Galactose & 28.79 \\
$p$-Nitrophenyl- $\beta$-D-cellobioside & $\beta$-Cellobiose & $\mathrm{ND}$ \\
$p$-Nitrophenyl- $\beta$-D-xylopyranoside & $\beta$-Xylose & 18.87 \\
Polydatin & $\beta$-Glucose & 422.21 \\
Esculin & $\beta$-Glucose & 126.69 \\
Oligosaccharides and polysaccharides & $-(1,4)-$-Glucose & - \\
Cellobiose & $\beta-(1,4)-$ Glucose & $\mathrm{ND}$ \\
Cellotriose & $\beta-(1,4)-$ Glucose & $\mathrm{ND}$ \\
Carboxymethyl cellulose & $\beta-(1,4)-$ Glucose & $\mathrm{ND}$ \\
Avicel & $\alpha-(1,4)$ and $\alpha-(1,6)$-Glucose & $\mathrm{ND}$ \\
Starch & $\mathrm{ND}$ \\
\hline
\end{tabular}

${ }^{a}$ Assay was determined at the optimum condition; ND, no detectable activity.

The kinetic parameters of r-MlBgl were determined using $p$ NPG as the substrate. The initial rate of the reaction was measured under optimal conditions. The kinetic parameters of $K_{\mathrm{m}}$ and $V_{\max }$ were determined by plotting the substrate concentration $v s$. the initial velocity of each reaction and subjecting the data to non linear regression analysis. Results showed that the $K_{\mathrm{m}}$ and $V_{\max }$ values of r-MlBgl were $0.69 \mathrm{mM}$ and $248.26 \mathrm{U} \cdot \mathrm{mg}^{-1}$ respectively. The $k_{\text {cat }}$ and the $k_{\text {cat }} / K_{\mathrm{m}}$ were $581.52 \mathrm{~s}^{-1}$ and $842.78 \mathrm{mM}^{-1} \cdot \mathrm{s}^{-1}$, respectively. $\beta$-Glucosidases from different sources of microorganisms have variable kinetic parameters of $K_{\mathrm{m}}$ and $k_{\text {cat }}$ values but usually lower than $1 \mathrm{mM}$ and $1000 \mathrm{~s}^{-1}$, respectively $[11,17,39]$. The detected $K_{\mathrm{m}}$ and $k_{\text {cat }}$ values of $\mathrm{r}-\mathrm{MlBgl}$ toward this substrate were within the same range. 


\subsection{Enzymatic Conversion of Polydatin to Resveratrol}

Enzymatic conversion of polydatin to resveratrol was determined by HPLC. The hydrolyzing parameters of r-MlBgl towards polydatin were investigated by Michaelis-Menten plots (Figure 5). The productivity of resveratrol was $1.28 \mathrm{mM} / \mathrm{h}$. The $K_{\mathrm{m}}, k_{\text {cat }}$ and $k_{\text {cat }} / K_{\mathrm{m}}$ values for polydatin were $0.67 \mathrm{mM}, 989 \mathrm{~s}^{-1}$ and $1476 \mathrm{mM}^{-1} \cdot \mathrm{s}^{-1}$, respectively. Due to the important role of resveratrol and its pharmacological properties, considerable scientific attention is being achieved in the enzymatic conversion of polydatin to resveratrol. It was reported that $\beta$-glucosidases from Lactobacillus kimchi and Aspergillus oryzae hydrolyze polydatin effectively. The comparison of productivity and kinetic parameters of $\mathrm{r}-\mathrm{MlBgl}$ with other $\beta$-glucosidases toward polydatin are seen in Table 3 . Compared with these reported $\beta$-glucosidases, $\mathrm{r}$-MlBgl exhibited the highest productivity of resveratrol of the $\beta$-glucosidases from Aspergillus oryzae and Lactobacillus kimchi per unit of enzyme [12,17]. r-MlBgl also exhibited higher $k_{\text {cat }}$ and $k_{\text {cat }} / K_{\mathrm{m}}$ values than $\beta$-glucosidase from Lactobacillus kimchi, indicating it is able to hydrolyze polydatin more effectively.

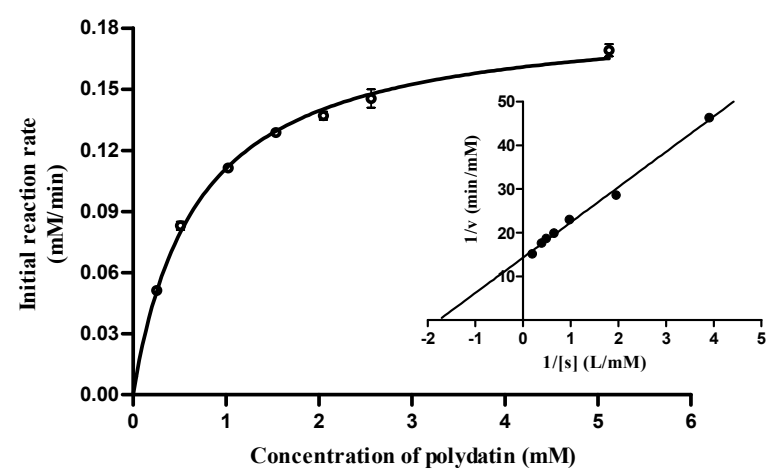

Figure 5. Michaelis-Menten plots for the reactions with substrate of polydatin. The inset shows the Lineweaver-Burk plots. Each data point represents the mean \pm SD of three independent experiments.

Table 3. A comparison of productivity and kinetic parameters of r-MlBgl for polydatin with other $\beta$-glucosidases.

\begin{tabular}{|c|c|c|c|c|c|c|c|}
\hline Enzyme Origin & Amounts & $\begin{array}{l}\text { Time } \\
\text { (h) }\end{array}$ & $\begin{array}{l}\text { Productivity } \\
(\mathrm{mM} / \mathrm{h})\end{array}$ & $\begin{array}{c}K_{\mathrm{m}} \\
(\mathrm{mM})\end{array}$ & $\begin{array}{c}k_{\text {cat }} \\
\left(\mathrm{s}^{-1}\right)\end{array}$ & $\begin{array}{c}k_{\mathrm{cat}} / K_{\mathrm{m}} \\
\left(\mathrm{mM}^{-1} \cdot \mathbf{s}^{-1}\right)\end{array}$ & References \\
\hline Lactobacillus kimchi & $3.28 \mu \mathrm{g} / \mathrm{mL}$ & 40 & 0.64 & 0.20 & 1.29 & 6.45 & [17] \\
\hline Aspergillus oryzae & $5 \mathrm{U} / \mathrm{mL}$ & 4 & 5.12 & NR & NR & NR & [12] \\
\hline Metagenomic library & $0.13 \mathrm{U} / \mathrm{mL}$ & 1 & $1.28^{b}$ & 0.67 & 989 & 1476 & This study \\
\hline
\end{tabular}

${ }^{a} \mathrm{NR}$, not reported; ${ }^{\mathrm{b}}$ The reaction mixture containing $0.125 \mathrm{U} / \mathrm{mL} \mathrm{r}-\mathrm{MlBgl}$ and $1 \mathrm{mg} / \mathrm{mL}$ polydatin was performed in $0.2 \mathrm{M}$ McIlvaine buffer $(\mathrm{pH} 7.0)$ at $30^{\circ} \mathrm{C}$ for $1 \mathrm{~h}$. The productivity $(\mathrm{mM} / \mathrm{h})$ was defined as the increase in the concentration of resveratrol produced in $1 \mathrm{~h}$ [41].

\section{Experimental Section}

\subsection{Strains, Vectors and Reagents}

Escherichia coli EPI300-T1R and Copycontrol pCC2FOS (Epicentre, Madison, WI, USA) were used as host strain and vector for construction of the metagenomic library. pET22b (+) (Novagen, Madison, WI, USA) was used as the expression vector to produce the target protein in Escherichia coli BL21(DE3) (Novagen). DNA isolation and purification kits, Escherichia coli DH5 $\alpha$, pMD19-T vector, restriction endonucleases, DNA polymerase, dNTPs, T4 DNA ligase and isopropyl- $\beta$-D-1-thiogalactopyranoside (IPTG) were purchased from TaKaRa. Substrates $p$-nitrophenyl- $\beta$-D-glucopyranoside $(p N P G)$, polydatin, and resveratrol standards were from Sigma-Aldrich. All other chemicals were of analytical grade unless otherwise stated. 


\subsection{Metagenomic Library Construction}

The topsoil samples $(0-10 \mathrm{~cm})$ were collected from the Mangrove Reserve of Sanya City $\left(18^{\circ} 15^{\prime} 16.32^{\prime \prime} \mathrm{N}, 109^{\circ} 30^{\prime} 28.10^{\prime \prime} \mathrm{E}\right)$, Hainan province of China. The samples were stored at $-20^{\circ} \mathrm{C}$ until the DNA extractions were performed. Extraction of the total genomic DNA from soil samples was performed according to the method reported with minor modifications [23]. The DNA fragments $(35-48 \mathrm{~kb})$ were obtained and purified by pulsed-field gel electrophoresis (PFGE). And then the metagenomic library was constructed following the instructions of the CopyControl Fosmid Library Production Kit.

\subsection{Screening of $\beta$-Glucosidase Gene MlBgl}

Recombinant Escherichia coli EPI300-T1R strains of the metagenomic library were replicated onto Luria-Bertani (LB) agar plates containing $0.1 \%$ esculin to detect $\beta$-glucosidase activity. The plates were incubated at $28^{\circ} \mathrm{C}$ for $16 \mathrm{~h}$ and then placed at room temperature for $2-3$ days. The clones that turned dark brown on the plate were selected as $\beta$-glucosidase positive recombinants. The fosmid DNA of positive clones were isolated and partially digested with Sau3A I. DNA fragments of $1-5 \mathrm{~kb}$ were recovered and ligated into pUC19 with BamH I digested. And then transformed to Escherichia coli DH5 $\alpha$. The subcloned library was rescreened of $\beta$-glucosidase activities and the plasmid from positive clones was sequenced.

\subsection{Sequence Analysis}

The sequence similarities and conserved motif of MlBgl was analyzed by BLAST program (version 2.3, http://www.ncbi.nlm.nih.gov/BLAST). Multiple sequence alignment of MlBgl with similar $\beta$-glucosidase sequences was carried out using the ClustalX (Version 2.0, EMBL-EBI) and DNAMAN (Version 6.0, Lynnon Biosoft Corp., San Ramon, CA, USA) program. The three-dimensional (3D) model of r-MlBgl was generated by homology modelling using the Swiss-Model server (http://swissmodel.expasy.org). The crystal structure of $\beta$-D-glucan exohydrolase isoenzyme ExoI (PDB code: 1EX1) was served as template for modelling the structure of r-MlBgl. The coloring and labeling of the 3D structures were performed by using PyMOL software (version 1.8, www.pymol.org).

\subsection{Gene Expression and Purification of Recombinant $\beta$-Glucosidase $r-M l B g l$}

The $\beta$-glucosidase gene MlBgl was amplified by using the primer pair of GCATGCCATGGGCGCACAGCAACCGGAATTGGCAG (Nco I digestion site underlined) and CCTCCGCTCGAGCAGCACGATCCCGGCTCCAAAG (Xho I digestion site underlined). The PCR product was digested with restriction endonucleases Nco I and Xho I, then ligated into pET-22b (+) vector which digested with the same enzymes. The recombinant plasmid pET-MlBgl was transformed into Escherichia coli BL21(DE3) to express the target protein. The transformed Escherichia coli BL21(DE3) cells carrying pET-MlBgl were cultured in LB medium containing ampicillin $(100 \mu \mathrm{g} / \mathrm{mL})$ at $37^{\circ} \mathrm{C}$. After inducing in $1 \mathrm{mM} \mathrm{IPTG}$ at $22{ }^{\circ} \mathrm{C}$ for $16 \mathrm{~h}$, cells were harvested, washed twice with Tris- $\mathrm{HCl}$ buffer ( $\mathrm{pH}$ 7.6), and lysed by sonication on ice for $20 \mathrm{~min}$ at a pulse frequency of $4 \mathrm{~s} / 4 \mathrm{~s}$. The lysate was centrifuged at $10,000 \mathrm{~g}$ for $20 \mathrm{~min}$ at $4{ }^{\circ} \mathrm{C}$. The supernatant was applied to a $\mathrm{Ni}^{2+}-\mathrm{NTA}$ agarose gel column for purification. The recombinant $\beta$-glucosidase r-MlBgl was eluted with $200 \mathrm{mM}$ imidazole and then dialyzed in deionized double-distilled $\mathrm{H}_{2} \mathrm{O}$ at $4{ }^{\circ} \mathrm{C}$ for $24 \mathrm{~h}$. The purified protein was detected with sodium dodecyl sulfate-polyacrylamide gel electrophoresis (SDS-PAGE). The protein concentration was determined by the Bradford method [42] with bovine serum albumin as standard.

\subsection{Enzyme Activity Assay}

$\beta$-Glucosidase activity was determined using $p$ NPG as the substrate [43]. The reaction mixure contained $1 \mu \mathrm{L}$ of appropriately diluted enzyme, $10 \mu \mathrm{L} 25 \mathrm{mM} p \mathrm{NPG}$, and $89 \mu \mathrm{L} 0.2 \mathrm{M}$ Mcllvaine buffer (pH 7.0). After incubation at $40{ }^{\circ} \mathrm{C}$ for $5 \mathrm{~min}$, the reaction was terminated with $50 \mu \mathrm{L} 1$ 
$\mathrm{M} \mathrm{Na}_{2} \mathrm{CO}_{3}$. The amount of liberated $p$-nitrophenol was measured by detecting the absorption at $405 \mathrm{~nm}$. The control was set by adding $50 \mu \mathrm{L} 1 \mathrm{M} \mathrm{Na}_{2} \mathrm{CO}_{3}$ before addition of the enzyme. One unit of $\beta$-glucosidase activity (U) was defined as the amount of enzyme that produced $1 \mu \mathrm{mol} p$-nitrophenol per min under the optimal conditions. To determine the $K_{\mathrm{m}}$ and $V_{\max }$ values towards $p \mathrm{NPG}$, a series of concentrations $(0.25-2.5 \mathrm{mM})$ of $p$ NPG in McIlvaine buffer $(\mathrm{pH} 7.0)$ were incubated at $40^{\circ} \mathrm{C}$ for $5 \mathrm{~min}$. The reaction starting and stopping conditions were the same as those used previously.

\subsection{Physico-Chemical Characterization of $r-M l B g l$}

The characterization of r-MlBgl was detected by using $p$ NPG as the substrate. The optimal reaction $\mathrm{pH}$ was tested in varying $\mathrm{pH}$ buffer $(\mathrm{pH} 3.0-11.0)$ at $40{ }^{\circ} \mathrm{C}$. The buffers used were $0.2 \mathrm{M}$ Mcllvaine buffer for $\mathrm{pH} 3.0-8.0$ and $0.05 \mathrm{M}$ glycine-NaOH buffer for $\mathrm{pH}$ 8.0-11.0. The optimal reaction temperature was determined in Mcllvaine buffer ( $\mathrm{pH}$ 7.0) at a temperature from 0 to $65^{\circ} \mathrm{C}$ at intervals of $5^{\circ} \mathrm{C}$. The thermal stability of $\mathrm{r}-\mathrm{MlBgl}$ was determined by measuring the residual activity after incubating enzyme at different temperatures from $0{ }^{\circ} \mathrm{C}$ to $45^{\circ} \mathrm{C}$ for $1 \mathrm{~h}$. To investigate the effects of different metal ions on enzyme activity, $1 \mathrm{mM}$ and $10 \mathrm{mM}$ (final concentration) of $\mathrm{Na}^{+}, \mathrm{K}^{+}, \mathrm{Li}^{+}$, $\mathrm{NH}_{4}{ }^{+}, \mathrm{Mg}^{2+}, \mathrm{Fe}^{3+}, \mathrm{Zn}^{2+}, \mathrm{Ca}^{2+}, \mathrm{Cu}^{2+}, \mathrm{Ni}^{2+}, \mathrm{Ba}^{2+}, \mathrm{Co}^{2+}$, EDTA, and SDS were individually added to the reaction system. All enzyme activities were determined in three independent experiments.

\subsection{Substrate Specificity}

Substrate specificity of r-MlBgl was determined by using $p$ NPG, $p$-nitrophenyl- $\beta$-D-galactopyranoside, $p$-nitrophenyl- $\beta$-D-cellobioside and $p$-nitrophenyl- $\beta$-D-xylopyranoside at $2.5 \mathrm{mM}$ final concentration. r-MlBgl activities on esculin, carboxymethylcellulose (CMC), xylan, avicel and starch as substrates at $1 \%$ concentration were also tested. The activities were estimated by assaying the reducing sugars via DNS (3,5-dinitrosalicylic acid) method [44]. The product from reaction of DNS and reducing sugar was brown on heating, and the amount of reducing sugar was determined by detecting the brown product at $\mathrm{OD}_{540}$ using the glucose curve as standard. Activities on cellobiose and cellotriose were determined by using the glucose assay kit. One unit of activity $(U)$ was defined as the amount of enzyme that produced $1 \mu \mathrm{mol}$ reducing sugar per min under the optimal conditions.

\subsection{Enzymatic Conversion of Polydatin to Resveratrol}

To determine the kinetic properties of recombinant r-MlBgl toward polydatin, $200 \mu \mathrm{L}$ reaction mixtures containing $0.0125 \mathrm{U}$ enzyme and a series of concentrations of polydatin $(0.256-5.12 \mathrm{mM})$ in McIlvaine buffer ( $\mathrm{pH} 7.0$ ) were incubated at $40^{\circ} \mathrm{C}$ for $5 \mathrm{~min}$. The reaction was stopped by adding $800 \mu \mathrm{L}$ methanol. For analysis of the amount of resveratrol produced, the reaction mixtures were diluted 10 times with methanol and filtered through a $0.22 \mu \mathrm{m}$ membrane prior to high performance liquid chromatography (HPLC). An Agilent system equipped with a reverse phase column C 18 $(4.6 \times 250 \mathrm{~mm}, 5 \mu \mathrm{m})$ was used in this study. The sample was injected and eluted with a linear gradient of solvent A ( $0.1 \%$ formic acid in water) and solvent B (100\% acetonitrile) from 95:5 to 20:80 for $45 \mathrm{~min}$, and then from 20:80 to $95: 5$ for $5 \mathrm{~min}$ at a flow rate of $1 \mathrm{~mL} / \mathrm{min}$. The UV absorption was measured at $306 \mathrm{~nm}$. The amount of polydatin and resveratrol in the samples were calculated using standard curves prepared from known concentrations of standards. All enzymatic conversions were determined in three independent experiments, and a reaction mixture with heat inactivated enzyme was used as a blank control. The kinetic parameters of $K_{\mathrm{m}}$ and $V_{\max }$ towards polydatin were subjected to nonlinear regression analysis with the GraphPad Prism 5.0 software (Version 5.0, GraphPad software Inc., San Diego, CA, USA).

\subsection{Nucleotide Sequence Accession Number}

The nucleotide sequences of the $\beta$-glucosidase gene MlBgl from the mangrove metagenomic library were deposited in the GenBank database under accession number KF424271. 


\section{Conclusions}

A metagenomic library of mangrove soil was constructed and a novel GH3 $\beta$-glucosidase was isolated by functional screening. The recombinant $\mathrm{r}-\mathrm{MlBgl}$ was overexpressed, purified, and characterized. r-MlBgl exhibited high relative activities at low temperature. It had strong substrate specificity that could only hydrolyze aryl $\beta$-glycosides. A very attractive characteristic of r-MlBgl was the high catalytic efficiency toward polydatin. The $k_{\text {cat }}, k_{\text {cat }} / K_{\mathrm{m}}$ and productivity of r-MlBgl toward polydatin were higher than the $\beta$-glucosidases previously reported. These properties make it a good candidate in enzymatic conversion of polydatin to resveratrol. This study also highlights the utility of the metagenomic approach in discovering novel $\beta$-glucosidases for hydrolysis of polydatin.

Acknowledgments: This work was supported by grants from the Administration of Ocean and Fisheries of Guangdong Province (GD2012-D01-002); the National High Technology Research and Development Program of China (NO.2012AA092104); the "Strategic Priority Research Program" of the Chinese Academy of Sciences (NO.XDA10030400); and the Natural Science Foundation of Guangdong Province, China (Grant No.2015A030310270).

Author Contributions: Zhimao Mai performed the experiments and wrote the manuscript. Hongfei Su analyzed the data and contributed reagents/materials/analysis tools. Si Zhang conceived and designed the experiments.

Conflicts of Interest: The authors declare no conflict of interest.

\section{References}

1. Bertelli, A.; Ferrara, F.; Diana, G.; Fulgenzi, A.; Corsi, M.; Ponti, W.; Ferrero, M.; Bertelli, A. Resveratrol, a natural stilbene in grapes and wine, enhances intraphagocytosis in human promonocytes: A co-factor in antiinflammatory and anticancer chemopreventive activity. Int. J. Tissue React. 1998, 21, 93-104.

2. Fremont, L. Biological effects of resveratrol. Life Sci. 2000, 66, 663-673. [CrossRef]

3. Jiang, L.; Gu, Y.; Ye, J.; Liu, F.; Zhao, Y.; Wang, C.; Xu, Y.; Cao, X.; Zhang, L.; Dong, W. Resveratrol prevents hepatic steatosis induced by hepatitis $C$ virus core protein. Biotechnol. Lett. 2012, 34, 2205-2212. [CrossRef] [PubMed]

4. Sánchez-Patán, F.; Monagas, M.; Moreno-Arribas, M.V.; Bartolomé, B. Determination of microbial phenolic acids in human faeces by UPLC-ESI-TQ MS. J. Agric. Food Chem. 2011, 59, 2241-2247. [CrossRef] [PubMed]

5. Wang, H.; Liu, L.; Guo, Y.X.; Dong, Y.S.; Zhang, D.J.; Xiu, Z.L. Biotransformation of piceid in Polygonum cuspidatum to resveratrol by Aspergillus oryzae. Appl. Microbiol. Biotechnol. 2007, 75, 763-768. [CrossRef] [PubMed]

6. Chong, Y.; Yan, A.; Yang, X.; Cai, Y.; Chen, J. An optimum fermentation model established by genetic algorithm for biotransformation from crude polydatin to resveratrol. Appl. Biochem. Biotechnol. 2012, 166, 446-457. [CrossRef] [PubMed]

7. Voorhorst, W.; Eggen, R.; Luesink, E.J.; De Vos, W. Characterization of the celB gene coding for beta-glucosidase from the hyperthermophilic archaeon Pyrococcus furiosus and its expression and site-directed mutation in Escherichia coli. J. Bacteriol. 1995, 177, 7105-7111. [PubMed]

8. Shewale, J. $\beta$-Glucosidase: Its role in cellulase synthesis and hydrolysis of cellulose. Int. J. Biochem. 1982, 14, 435-443. [CrossRef]

9. Hu, Y.; Luan, H.; Zhou, K.; Ge, G.; Yang, S.; Yang, L. Purification and characterization of a novel glycosidase from the china white jade snail (Achatina fulica) showing transglycosylation activity. Enzym. Microb. Technol. 2008, 43, 35-42. [CrossRef]

10. González-Pombo, P.; Fariña, L.; Carrau, F.; Batista-Viera, F.; Brena, B.M. A novel extracellular $\beta$-glucosidase from Issatchenkia terricola: Isolation, immobilization and application for aroma enhancement of white Muscat wine. Process Biochem. 2011, 46, 385-389. [CrossRef]

11. Du, L.; Wang, Z.; Zhao, Y.; Huang, J.; Pang, H.; Wei, Y.; Lin, L.; Huang, R. A $\beta$-glucosidase from Novosphingobium sp. GX9 with high catalytic efficiency toward isoflavonoid glycoside hydrolysis and (+)-catechin transglycosylation. Appl. Microbiol. Biotechnol. 2014, 98, 7069-7079. [CrossRef] [PubMed]

12. Chen, M.; Li, D.; Gao, Z.; Zhang, C. Enzymatic transformation of polydatin to resveratrol by piceid- $\beta$-D-glucosidase from Aspergillus oryzae. Bioprocess Biosyst. Eng. 2014, 37, 1411-1416. [CrossRef] [PubMed] 
13. Loughlin, W.A. Biotransformations in organic synthesis. Bioresour. Technol. 2000, 74, 49-62. [CrossRef]

14. Tian, T.; Sun, Q.; Shen, J.; Zhang, T.; Gao, P.; Sun, Q. Microbial transformation of polydatin and emodin-8- $\beta$-D-glucoside of Polygonum cuspidatum Sieb. et Zucc into resveratrol and emodin respectively by Rhizopus microsporus. World J. Microbiol. Biotechnol. 2008, 24, 861-866. [CrossRef]

15. Jin, S.; Luo, M.; Wang, W.; Zhao, C.J.; Gu, C.B.; Li, C.Y.; Zu, Y.G.; Fu, Y.J.; Guan, Y. Biotransformation of polydatin to resveratrol in Polygonum cuspidatum roots by highly immobilized edible Aspergillus niger and Yeast. Bioresour. Technol. 2013, 136, 766-770. [CrossRef] [PubMed]

16. Zhang, C.; Li, D.; Yu, H.; Zhang, B.; Jin, F. Purification and characterization of piceid- $\beta$-D-glucosidase from Aspergillus oryzae. Process Biochem. 2007, 42, 83-88. [CrossRef]

17. Ko, J.A.; Park, J.; Kwon, H.; Ryu, Y.; Jeong, H.; Park, S.; Kim, C.; Oh, H.; Park, C.; Lim, Y. Purification and functional characterization of the first stilbene glucoside-specific $\beta$-glucosidase isolated from Lactobacillus kimchi. Enzyme Microbiol. Technol. 2014, 67, 59-66. [CrossRef]

18. Amann, R.I.; Ludwig, W.; Schleifer, K.H. Phylogenetic identification and in situ detection of individual microbial cells without cultivation. Microbiol. Rev. 1995, 59, 143-169. [PubMed]

19. Jiang, C.; Li, S.X.; Luo, F.F.; Jin, K.; Wang, Q.; Hao, Z.Y.; Wu, L.L.; Zhao, G.C.; Ma, G.F.; Shen, P.H. Biochemical characterization of two novel $\beta$-glucosidase genes by metagenome expression cloning. Bioresour. Technol. 2011, 102, 3272-3278. [CrossRef] [PubMed]

20. Li, G.; Jiang, Y.; Fan, X.J.; Liu, Y.H. Molecular cloning and characterization of a novel $\beta$-glucosidase with high hydrolyzing ability for soybean isoflavone glycosides and glucose-tolerance from soil metagenomic library. Bioresour. Technol. 2012, 123, 15-22. [CrossRef] [PubMed]

21. Feng, Y.; Duan, C.J.; Liu, L.; Tang, J.L.; Feng, J.X. Properties of a metagenome-derived $\beta$-glucosidase from the contents of rabbit cecum. Biosci. Biotechnol. Biochem. 2009, 73, 1470-1473. [CrossRef] [PubMed]

22. Nacke, H.; Engelhaupt, M.; Brady, S.; Fischer, C.; Tautzt, J.; Daniel, R. Identification and characterization of novel cellulolytic and hemicellulolytic genes and enzymes derived from German grassland soil metagenomes. Biotechnol. Lett. 2012, 34, 663-675. [CrossRef] [PubMed]

23. Mai, Z.; Su, H.; Li, L.; Zhang, S. Construction of a mangrove soil metagenome library and identification of two novel $\beta$-glucosidase genes. Biotechnol. Bull. 2014, 6, 168-172.

24. Kim, S.J.; Lee, C.M.; Han, B.R.; Kim, M.Y.; Yeo, Y.S.; Yoon, S.H.; Koo, B.S.; Jun, H.K. Characterization of a gene encoding cellulase from uncultured soil bacteria. FEMS Microbiol. Lett. 2008, 282, 44-51. [CrossRef] [PubMed]

25. Jiang, C.; Hao, Z.Y.; Jin, K.; Li, S.X.; Che, Z.Q.; Ma, G.F.; Wu, B. Identification of a metagenome-derived $\beta$-glucosidase from bioreactor contents. J. Mol. Catal. B 2010, 63, 11-16. [CrossRef]

26. Mao, X.; Hong, Y.; Shao, Z.; Zhao, Y.; Liu, Z. A novel cold-active and alkali-stable $\beta$-glucosidase gene isolated from the marine bacterium Martelella mediterrânea. Appl. Biochem. Biotechnol. 2010, 162, 2136-2148. [CrossRef] [PubMed]

27. Li, Y.K.; Chir, J.; Tanaka, S.; Chen, F.Y. Identification of the general acid/base catalyst of a family 3ß-glucosidase from Flavobacterium meningosepticum. Biochemistry 2002, 41, 2751-2759. [CrossRef] [PubMed]

28. Vocadlo, D.J.; Mayer, C.; He, S.; Withers, S.G. Mechanism of action and identification of Asp242 as the catalytic nucleophile of Vibrio furnisii $N$-acetyl- $\beta$-D-glucosaminidase using 2-acetamido-2-deoxy5-fluoro- $\alpha$-L-idopyranosyl fluoride. Biochemistry 2000, 39, 117-126. [CrossRef] [PubMed]

29. Zechel, D.L.; Withers, S.G. Glycosidase mechanisms: anatomy of a finely tuned catalyst. Acc. Chem. Res. 2000, 33, 11-18. [PubMed]

30. Varghese, J.N.; Hrmova, M.; Fincher, G.B. Three-dimensional structure of a barley $\beta$-D-glucan exohydrolase, a family 3 glycosyl hydrolase. Structure 1999, 7, 179-190. [CrossRef]

31. Todaro, A.; Palmeri, R.; Barbagallo, R.N.; Pifferi, P.G.; Spagna, G. Increase of trans-resveratrol in typical Sicilian wine using $\beta$-glucosidase from various sources. Food Chem. 2008, 107, 1570-1575. [CrossRef]

32. Shipkowski, S.; Brenchley, J.E. Characterization of an unusual cold-active $\beta$-glucosidase belonging to family 3 of the glycoside hydrolases from the psychrophilic isolate Paenibacillus sp. strain C7. Appl. Environ. Microbiol. 2005, 71, 4225-4232. [CrossRef] [PubMed]

33. Siddiqui, K.S.; Cavicchioli, R. Cold-adapted enzymes. Annu. Rev. Biochem. 2006, 75, 403-433. [CrossRef] [PubMed] 
34. Crespim, E.; Zanphorlin, L.M.; de Souza, F.H.; Diogo, J.A.; Gazolla, A.C.; Machado, C.B.; Figueiredo, F.; Sousa, A.S.; Nóbrega, F.; Pellizari, V.H. A novel cold-adapted and glucose-tolerant GH1 $\beta$-glucosidase from Exiguobacterium antarcticum B7. Int. J. Biol. Macromol. 2016, 82, 375-380. [CrossRef] [PubMed]

35. Fan, H.X.; Miao, L.L.; Liu, Y.; Liu, H.C.; Liu, Z.P. Gene cloning and characterization of a cold-adapted $\beta$-glucosidase belonging to glycosyl hydrolase family 1 from a psychrotolerant bacterium Micrococcus antarcticus. Enzym. Microbiol. Technol. 2011, 49, 94-99. [CrossRef] [PubMed]

36. Gu, N.Y.; Kim, J.L.; Kim, H.J.; You, D.J.; Kim, H.W.; Jeon, S.J. Gene cloning and enzymatic properties of hyperthermostable $\beta$-glycosidase from Thermus thermophilus HJ6. J. Biosci. Bioeng. 2009, 107, 21-26. [CrossRef] [PubMed]

37. Parry, N.; Beever, D.; Owen, E.; Vandenberghe, I.; Van Beeumen, J.; Bhat, M. Biochemical characterization and mechanism of action of a thermostable $\beta$-glucosidase purified from Thermoascus aurantiacus. Biochem. J. 2001, 353, 117-127. [CrossRef] [PubMed]

38. Zhang, N.; Suen, W.C.; Windsor, W.; Xiao, L.; Madison, V.; Zaks, A. Improving tolerance of Candida antarctica lipase B towards irreversible thermal inactivation through directed evolution. Protein Eng. 2003, 16, 599-605. [CrossRef] [PubMed]

39. Kudo, K.; Watanabe, A.; Ujiie, S.; Shintani, T.; Gomi, K. Purification and enzymatic characterization of secretory glycoside hydrolase family 3 (GH3) aryl $\beta$-glucosidases screened from Aspergillus oryzae genome. J. Biosci. Bioeng. 2015, 120, 614-623. [CrossRef] [PubMed]

40. Bhatia, Y.; Mishra, S.; Bisaria, V. Microbial $\beta$-glucosidases: Cloning, properties, and applications. Crit. Rev. Biotechnol. 2002, 22, 375-407. [CrossRef] [PubMed]

41. Yeom, S.J.; Kim, B.N.; Kim, Y.S.; Oh, D.K. Hydrolysis of isoflavone glycosides by a thermostable $\beta$-glucosidase from Pyrococcus furiosus. J. Agric. Food Chem. 2012, 60, 1535-1541. [CrossRef] [PubMed]

42. Bradford, M.M. A rapid and sensitive method for the quantitation of microgram quantities of protein utilizing the principle of protein-dye binding. Anal. Biochem. 1976, 72, 248-254. [CrossRef]

43. Mai, Z.; Yang, J.; Tian, X.; Li, J.; Zhang, S. Gene cloning and characterization of a novel salt-tolerant and glucose-enhanced $\beta$-glucosidase from a marine Streptomycete. Appl. Biochem. Biotechnol. 2013, 169, 1512-1522. [CrossRef] [PubMed]

44. Somogyi, M. Notes on sugar determination. J. Biol. Chem. 1952, 195, $19-23$.

(C) 2016 by the authors; licensee MDPI, Basel, Switzerland. This article is an open access article distributed under the terms and conditions of the Creative Commons by Attribution (CC-BY) license (http://creativecommons.org/licenses/by/4.0/). 